\title{
Clinical Observations, Plasma Retinol Concentrations, and In Vitro Lymphocyte Functions in Children With Sickle Cell Disease
}

\author{
Solo R. Kuvibidila, PhD, ${ }^{1}$ Renée Gardner, MD, ${ }^{1}$ Maria Velez, MD, ${ }^{1}$ Raj Warrier, $M D^{1-3}$ \\ ${ }^{1}$ Department of Pediatrics, Louisiana State University Health Sciences Center, New Orleans, LA ${ }^{2}$ Department of Pediatrics, Ochsner Clinic \\ Foundation, New Orleans, LA ${ }^{3}$ The University of Queensland School of Medicine, Ochsner Clinical School, New Orleans, LA
}

Background: Children with sickle cell disease (SCD) often have infections, growth deficits, and impaired immunity, problems that also are observed in individuals with a vitamin A deficiency (plasma retinol concentration $<20 \mu \mathrm{g} / \mathrm{dL}$ ). The goal of this study was to investigate the association between vitamin A, health status, and the in vitro immune function of children with SCD. Methods: Fifty-nine children (40 SS, $11 \mathrm{SC}$, and 8 S $\beta^{\text {thalassemia }}\left[S \beta^{\text {thal }}\right.$ ] hemoglobin genotypes) 9 months to 18 years old were investigated for plasma levels of retinol, retinol binding protein, C-reactive protein, alpha-1-acid glycoprotein, lymphocyte proliferation, and interleukin (IL)-2 activity in supernatant of phytohemagglutinin-treated lymphocytes.

Results: The plasma retinol concentrations of children with SCD (mean 57.6 $\mu \mathrm{g} / \mathrm{dL}$, range 4.6-116 $\mu \mathrm{g} / \mathrm{dL}$ ) were not different from those of 21 normal individuals (mean $62 \mu \mathrm{g} / \mathrm{dL}$, range $28.7-162 \mu \mathrm{g} / \mathrm{dL}$ ). Plasma retinol concentrations did not vary by hemoglobin genotype but were lower in boys than in girls $(P<0.05)$ and were also lower in children with inflammation $(P=0.1)$. Seven children (11.9\%) (6 HbSS, $1 \mathrm{HbS}^{\text {Othal }}$ ) were vitamin A-deficient, and 9 children (15.3\%) had suboptimal vitamin A status (plasma retinol concentration of $20-29 \mu \mathrm{g} / \mathrm{dL}$ ). Children with vitamin A deficiency had slightly lower height $(P=0.09)$ and weight mean percentiles, lymphocyte proliferative responses, and IL-2 activity $(P>0.1)$, but higher means of C-reactive protein $(P=0.05)$, pain crisis episodes and inflammation $(P=0.1)$, and health scores $(P>0.1)$ than children who were not vitamin A-deficient. Lymphocyte proliferative responses negatively correlated with health score, pain crisis episodes, and blood units received, but positively correlated with retinol binding protein $(P<0.05$ to $P=0.1)$.

Conclusion: Identification and correction of suboptimal vitamin A status in children with SCD may improve immunity and attenuate certain health complications associated with this disease.

Keywords: Anemia-sickle cell, infection, inflammation, interleukin-2, lymphocyte proliferation, vitamin A

Address correspondence to Solo R. Kuvibidila, PhD, c/o Renée Gardner, MD, Department of Pediatrics, Louisiana State University Health Sciences Center, 200 Henry Clay, New Orleans, LA 70118. Tel: (504) 896-9740. Email: solokuv@msn.com

\section{INTRODUCTION}

The role of vitamin $\mathrm{A}$ in morbidity and mortality resulting from infectious illnesses in humans and laboratory animals has been well established. ${ }^{1,2}$ Vitamin A deficiency (plasma retinol $<20 \mu \mathrm{g} / \mathrm{dL}$ ) impairs antibody responses to $\mathrm{T}$ celldependent antigens and immunoglobulin (Ig) $M$ switching to $\operatorname{lgA}$, decreases the percentage of Th2+ cells, impairs $\mathrm{T}$ cell homing in the gut (one of the main routes of pathogen entry into the body), increases gut permeability to pathogens and antigens, and increases susceptibility to infections. $^{3-7}$ Increased susceptibility to infection reduces growth rate, either through nutrient loss or by reduced food intake. Vitamin A deficiency also induces a proinflammatory response with elevated blood levels of type 1 cytokines such as tumor necrosis factor-alpha (TNF- $\alpha$ ) and interferon gamma but low antiinflammatory cytokines such as interleukin (IL)-4 and IL-10., 2,3

In a previous study involving 34 children with sickle cell disease (SCD), we observed that almost one in every two children had retinol binding protein $<30 \mathrm{mg} / \mathrm{L}^{8}{ }^{8}$ In contrast, only $20 \%$ of children had a transferrin concentration $<2 \mathrm{~g} / \mathrm{L}$, and no child had albumin levels $<35 \mathrm{~g} / \mathrm{L}$. The data suggested that suboptimal vitamin A status (as suggested by low plasma retinol binding protein concentration) rather than general protein energy malnutrition might have been responsible for the low retinol binding protein concentrations.

Growth retardation (low body weight for age, height for age, body fat, and delayed skeletal maturation) is common in children with SCD. ${ }^{9-12}$ The mechanisms of growth retardation are likely multifactorial and may involve deficits 
in protein, energy, and micronutrients such as zinc and vitamin A. $^{13-16}$

Although numerous studies have been conducted on the effect of deficits or supplementation of certain micronutrients, specifically zinc, on in vitro immune function and infection rates in children with SCD, there is a paucity of data on vitamin A status in the same population. ${ }^{13-15}$ This study was designed to investigate (1) vitamin A status in children with SCD who present to Children's Hospital of New Orleans; (2) whether suboptimal vitamin A status is associated with poor clinical status and growth deficits and with altered in vitro immune responses of peripheral blood mononuclear cells in these patients; (3) whether hemoglobin genotypes, inflammation, and/or sex are confounding factors in impaired in vitro lymphocyte function associated with suboptimal vitamin A status in this population.

\section{METHODS}

\section{Study Population and Design}

The study was approved by the Louisiana State University Health Sciences Center (LSUHSC) Institutional Review Board and Children's Hospital of New Orleans (Protocol \#1789). Children whose data are included in this analysis were enrolled in a prospective study on the association between nutritional status and lymphocyte proliferation and certain complications usually associated with SCD. Inclusion criteria were (1) patients were registered at Children's Hospital of New Orleans and received primary healthcare services related to SCD from the LSUHSC hematology/oncology physicians; (2) age 0.5 to 18 years; (3) boys and girls with $\mathrm{HbSS}, \mathrm{HbSC}$, and/or $\mathrm{HbS} \beta^{\text {thalassemia }}\left(\mathrm{HbS} \beta^{\text {thal }}\right.$ ) genotypes; and (4) patients who had not received bone marrow transplantation to correct hemoglobinopathy, splenectomy, or other major surgery related and unrelated to SCD. Patients who did not fulfill the above criteria were excluded. Prior to 1997, hydroxyurea was not prescribed to children with SCD at Children's Hospital of New Orleans, and none of the patients had received this drug.

A letter of invitation to participate in the study was sent to parents and guardians of all potential patients that briefly described the goal of the study. Additionally, parents/guardians were briefed during clinic visits. Among the 90 children who signed a consent form, 31 children were excluded from the analysis because of missing data on at least 3 measurements (markers of inflammation, biochemical markers of nutritional status, or plasma retinol concentration).

\section{Blood Drawing and Chart Review}

During clinic visits, blood samples $(2-4 \mathrm{~mL})$ were drawn in heparinized vacutainers under stable conditions from 59 children with SCD who were 9 months to 18 years old. Two hundred microliters $(200 \mu \mathrm{L})$ were removed for measurement of hemoglobin, hematocrit, and white blood cell counts by standard techniques. The remaining blood samples were centrifuged at $2,000 \mathrm{rpm}$ at room temperature for 10 minutes. Plasma was aspirated and aliquoted in $500 \mu \mathrm{L}$ volumes and immediately frozen at $-70^{\circ} \mathrm{C}$ until used for various measurements. Plasma retinol was measured by fluorescence spectrometry. For quality control, plasma retinol also was measured in frozen plasma samples obtained from individuals without SCD (7 LSUHSC laboratory employees [ 4 males and 3 females, age range $38-46$ years, mean 43 years] and 14 children [ 8 males and 6 females, age range 3-18 years, mean 8.5 years]).

Information on infections, pain crises, anthropometry weight, height, age, hemoglobin genotype, and blood transfusions was obtained from patients' charts for the period January 1994 through December 1996. To rule out the possibility that abnormal plasma retinol levels were attributable to inflammation, C-reactive protein (CRP) and alpha-1-acid glycoprotein (AGP) were measured by radial immunodiffusion, and TNF- $\alpha$ was measured by enzyme-linked immunosorbent assay. Inflammation was considered present when AGP and/or CRP were $>1 \mathrm{~g} / \mathrm{L}$ and $>10 \mathrm{mg} / \mathrm{L}$, respectively. Retinol binding protein was also measured by radial immunodiffusion because its plasma levels are reduced by vitamin A deficiency independently of inflammation and overt protein-energy malnutrition, and levels $<30 \mathrm{mg} / \mathrm{L}$ are considered abnormal. ${ }^{17,18}$

Growth deficits were present when either weight or height was below the $10^{\text {th }}$ percentile. Health scores were defined as 0 (no pain crisis episodes, infections, hospital admissions, or blood transfusions during the study period) or $\geq 1$ (the sum of pain crisis episodes, infections, hospital admissions, and blood transfusions received during the study period).

\section{Lymphocyte Proliferation}

Mononuclear cells were isolated by density gradient centrifugation on Ficoll-Hypaque from blood samples collected in heparinized blood. Cell viability was determined by trypan blue exclusion test. Lymphocyte proliferation was assessed by incubating $0.20 \times 10^{6}$ viable cells per $200 \mu \mathrm{L}$ of culture medium in the presence of $0-15 \mu \mathrm{g} / \mathrm{mL}$ phytohemagglutinin (PHA) at $37^{\circ} \mathrm{C}, 5 \% \mathrm{CO}_{2}$ in a humidified atmosphere. Per liter of RPMI-1640, the culture medium contained $100 \mathrm{~mL}$ heat-inactivated human $A B$ serum, $5 \times 10^{4}$ units penicillin, $50 \mathrm{mg}$ streptomycin, $1 \mathrm{mmol}$ sodium pyruvate, $0.1 \mathrm{mmol}$ nonessential amino acids, $2 \mathrm{mmol}$ L-glutamine, and $50 \mu \mathrm{mol} \beta$ mercaptoethanol. After 48 hours of incubation, cultures (made in triplicate) were pulsed with $1 \mu \mathrm{Ci}{ }^{3} \mathrm{H}$-thymidine and further incubated for 24 hours under identical conditions. The rate of cell proliferation was assessed by estimating the amount of radioactivity uptake (incorporated into DNA expressed as counts per minute) in a liquid scintillation counter as we previously reported. ${ }^{19}$

\section{Interleukin-2 Study}

Macrocultures containing $2 \times 10^{6}$ viable cells were mixed with $0-15 \mu \mathrm{g}$ PHA in a total volume of $1 \mathrm{~mL}$, transferred to round bottom $12 \times 75 \mathrm{~mm}$ culture tubes, and incubated in identical conditions as microcultures. After 48 hours, the tubes were centrifuged at 400 times gravity for 10 minutes. The supernatant was collected, aliquoted in $500 \mu \mathrm{L}$ samples, and immediately frozen at $-70^{\circ} \mathrm{C}$. The IL-2 activity in the supernatant was assessed by the growth of the IL-2dependent CTLL-2 cell line as described in the literature. ${ }^{20}$

\section{Statistical Analysis}

Descriptive status, analysis of variance, Pearson correlation coefficient, and chi-square test were performed with MYSTAT, second edition (SYSTAT Software, Inc.). ${ }^{21}$ Vitamin A status, IL-2 concentrations, and lymphocyte proliferative responses to PHA were analyzed as a function of sex, retinol binding protein, inflammation, and health scores. Multiple 
Table 1. Demographic Characteristics of the Study Population

\begin{tabular}{|c|c|c|c|c|c|}
\hline & \multicolumn{3}{|c|}{ Hemoglobin Genotype } & \multirow[b]{2}{*}{ Total } & \multirow[b]{2}{*}{ Mean Age, years, \pm SEM } \\
\hline & HbSS & HbSC & $\mathrm{HbS}^{\text {thal }}$ & & \\
\hline Boys & 23 & 7 & 4 & 34 & $7.63 \pm 0.71$ \\
\hline Girls & 17 & 4 & 4 & 25 & $7.63 \pm 1.00$ \\
\hline Total & 40 & 11 & 8 & 59 & $7.63 \pm 0.59$ \\
\hline Mean age, years, \pm SEM & $8.20 \pm 0.66^{b}$ & $5.03 \pm 1.24^{\mathrm{a}}$ & $8.34 \pm 2.02^{b}$ & & $7.63 \pm 0.59$ \\
\hline
\end{tabular}

Note: Two boys and one girl had $\mathrm{HbS} \beta^{0}$ genotype. The mean \pm SEM ages in years of children with $\mathrm{HbS} \beta^{0}(\mathrm{n}=3)$ and $\mathrm{HbS} \beta^{+}(\mathrm{n}=5)$ were $9.17 \pm 2.41$ and $7.85 \pm 5.43$, respectively (and were not significantly different). Children with $\mathrm{HbSC}$ genotype were younger than those with $\mathrm{HbSS}$ or $\mathrm{HbS} \beta^{\text {thal }}$ $(a<b ; P<0.05)$.

regression analysis was computed with IL-2 and/or lymphocyte proliferation as dependent variables and health status (plasma retinol concentration, weight, height, infection, blood transfusion, acute phase proteins, retinol binding protein, hemoglobin genotype, and hematologic measurements) as independent variables. The level of significance was set at $P<0.05$.

\section{RESULTS}

\section{Assessment of Clinical Status}

The mean \pm SEM age of the 59 study subjects was $7.63 \pm 0.59$ years. The cohort included 34 boys and 25 girls. As shown in Table 1, 67.8\% of patients had HbSS genotype. Children with HbSC genotype were younger than those with $\mathrm{HbSS}$ and $\mathrm{HbS} \beta^{\text {thal }}$ genotypes $(P<0.05)$. Of the 8 SCD children with $\beta$-thalassemia, 3 had $\mathrm{HbS} \beta^{\text {othal }}$ and 5 had $\mathrm{HbS}^{\text {thal }}$ genotypes. Mean concentrations of plasma retinol were not different among the 3 groups of hemoglobin genotypes, and they also were not significantly different from those of the laboratory controls or the 14 blood samples that were obtained from children without SCD (Table 2).

Seven of the 59 (11.9\%) children (age range, 5.5-13.58 years) had plasma retinol concentrations below normal $(<20 \mu \mathrm{g} / \mathrm{dL})$, and 9 other children (15.3\%; 5 boys with HbSS genotype, 2 girls with HbSS genotype, and 2 boys with $\mathrm{HbS}^{+ \text {thal }}$ ) had suboptimal plasma retinol concentra-

Table 2. Plasma Retinol Levels in Patients and Controls

\begin{tabular}{|c|c|c|c|}
\hline Group & $\mathbf{n}$ & $\begin{array}{c}\text { Mean ( } \pm \text { SEM) } \\
\text { Plasma } \\
\text { Retinol Level, } \\
\mu \mathrm{g} / \mathrm{dL}\end{array}$ & $\begin{array}{c}\text { Plasma } \\
\text { Retinol } \\
\text { Range, } \\
\mu \mathrm{g} / \mathrm{dL}\end{array}$ \\
\hline Children with HbSS & 40 & $57.1 \pm 4.7$ & 6-116 \\
\hline Children with $\mathrm{HbSC}$ & 11 & $60.9 \pm 5.7$ & $39-87$ \\
\hline Children with $\mathrm{HbS}^{\text {thal }}$ & 8 & $55.5 \pm 12.8$ & 4.6-109 \\
\hline $\begin{array}{l}\text { Children in the } \\
\text { control group }\end{array}$ & 14 & $59.0 \pm 5.88$ & 28.7-119 \\
\hline $\begin{array}{l}\text { Laboratory } \\
\text { employees }\end{array}$ & 7 & $70.0 \pm 17.39$ & $43.0-162$ \\
\hline All patients & 59 & $57.6 \pm 3.7$ & 4.6-116 \\
\hline All controls & 21 & $62 \pm 6.5$ & 28.7-162 \\
\hline
\end{tabular}

Note: No significant differences were observed between patients and the combined controls and/or by hemoglobin genotype. tions of $20-29 \mu \mathrm{g} / \mathrm{dL} .{ }^{22-24}$ None of the plasma samples obtained from laboratory employees or from children without SCD had plasma retinol concentrations below normal. Children with plasma retinol concentrations below normal tended to have lower means for height percentile $(P=0.09)$ and weight percentile $(P>0.1)$ but higher means of pain crisis episodes $(P=0.05)$, CRP $(P=0.05)$, and inflammation scores $(P=0.07)$ (Table 3$)$. However, all other measurements showed no significant differences between the 2 groups of children with SCD.

Among the 7 patients with plasma retinol levels below normal, 5 boys and 1 girl had HbSS genotype, and the seventh child was a boy with $\mathrm{HbS} \beta^{\text {Othal }}$ genotype. When the 5 boys with plasma retinol concentrations below normal and HbSS genotype were compared with 18 boys having the same hemoglobin genotype but with plasma retinol within the normal range, we again observed the following trend: higher mean CRP levels $(P=0.08)$ and inflammatory score $(P=0.1)$. No significant differences in the means of hematologic measurements and TNF- $\alpha$ concentrations were observed among vitamin A-deficient and vitamin A-adequate children.

Because only 1 girl had plasma retinol below normal, statistical analysis of various measurements could not be performed as a function of sex and vitamin A status. However, in the overall study population, girls had higher mean plasma retinol concentrations than boys (Table $4, P<0.05$ ). The means for weight and height percentiles tended to be higher in girls than boys, but mean infection episodes, inflammation scores, CRP, and TNF- $\alpha$ concentrations were lower in girls than boys, although differences were not statistically significant (Table 4). Although inflammation was associated with slightly lower mean plasma retinol concentration $(P=0.1)$, it did not significantly affect other health indices (Table 5, $P>0.1$ ).

As shown in Figure 1, a higher percentage of children with plasma retinol below normal had at least one episode of pain crisis $(P<0.05)$, had inflammation $(P=0.1)$, or had weight below the $10^{\text {th }}$ percentile $(P>0.1)$ compared to children with concentrations within the normal range. However, the percentages of children with SCD who had white blood cell counts $>15 \times 10^{6} \mathrm{~mL}$ did not differ by plasma retinol concentrations (data not shown).

\section{Lymphocyte Proliferation as Function of Plasma Retinol Levels, Inflammation, and Health Scores}

At all PHA concentration levels tested, the rate of DNA synthesis (Figure 2A) tended to be lower (mean decrease 
Kuvibidila, SR

Table 3. Mean ( \pm SEM) Age and Clinical Status of Children With Sickle Cell Disease as a Function of Plasma Retinol Concentration

\begin{tabular}{|c|c|c|c|c|c|c|}
\hline Variable & $\begin{array}{c}\text { Plasma Retinol } \\
<20 \mu \mathrm{g} / \mathrm{dL} \\
(\mathrm{n}=7)^{\mathrm{a}}\end{array}$ & $\begin{array}{c}\text { Plasma Retinol } \\
\geq 20 \mu \mathrm{g} / \mathrm{dL} \\
(\mathrm{n}=52)^{\mathrm{a}}\end{array}$ & $P$ Value & $\begin{array}{c}\text { Plasma Retinol } \\
<20 \mu \mathrm{g} / \mathrm{dL} \\
(\mathrm{n}=5 \text { boys } \\
\text { with HbSS) }\end{array}$ & $\begin{array}{c}\text { Plasma Retinol } \\
\geq 20 \mu \mathrm{g} / \mathrm{dL} \\
\text { ( } \mathrm{n}=18 \text { boys } \\
\text { with HbSS) }\end{array}$ & $P$ Value \\
\hline Age, years & $8.81 \pm 1.1$ & $7.47 \pm 0.65$ & & $8.87 \pm 1.51$ & $7.22 \pm 0.80$ & \\
\hline Weight, kg & $26.83 \pm 2.82$ & $25.54 \pm 2.33$ & & $25.38 \pm 3.35$ & $22.53 \pm 2.25$ & \\
\hline Weight percentile & $28.21 \pm 10.77$ & $37.72 \pm 4.62$ & & $20.50 \pm 9.25$ & $23.06 \pm 5.89$ & \\
\hline Height, $\mathrm{cm}$ & $131.5 \pm 6.22$ & $119.26 \pm 4.45$ & & $128.8 \pm 7.52$ & $118.64 \pm 6.99$ & \\
\hline Height percentile & $22.5 \pm 5.82$ & $40.28 \pm 4.87$ & 0.09 & $25.07 \pm 6.61$ & $26.31 \pm 7.46$ & \\
\hline Pain crises & $1.57 \pm 0.43$ & $0.72 \pm 0.19$ & 0.05 & $1.40 \pm 0.51$ & $0.82 \pm 0.23$ & \\
\hline Units of blood & $0.71 \pm 0.71$ & $1.17 \pm 0.33$ & & $1.00 \pm 0.998$ & $1.35 \pm 0.64$ & \\
\hline Infections & $0.57 \pm 0.297$ & $0.58 \pm 0.13$ & & $0.60 \pm 0.399$ & $0.81 \pm 0.28$ & \\
\hline Hospitalizations & $1.86 \pm 0.96$ & $1.43 \pm 0.27$ & & $1.20 \pm 0.582$ & $2.07 \pm 0.59$ & \\
\hline Hematocrit, \% & $26.5 \pm 1.87$ & $27.78 \pm 0.69$ & & $25.10 \pm 2.28$ & $24.22 \pm 0.78$ & \\
\hline Hemoglobin, $\mathrm{g} / \mathrm{dL}$ & $8.50 \pm 0.54$ & $8.79 \pm 0.2$ & & $8.22 \pm 0.64$ & $7.74 \pm 0.18$ & \\
\hline White blood cells $\times 10^{6} / \mathrm{mL}$ & $12.10 \pm 0.97$ & $12.69 \pm 0.75$ & & $11.57 \pm 1.11$ & $14.57 \pm 1.26$ & \\
\hline C-reactive protein, $\mathrm{mg} / \mathrm{L}$ & $18.27 \pm 12.8$ & $5.50 \pm 1.64$ & 0.05 & $25.58 \pm 17.23$ & $8.38 \pm 4.24$ & 0.08 \\
\hline Alpha-1-acid glycoprotein, g/L & $071 \pm 0.19$ & $0.69 \pm 0.04$ & & $0.83 \pm 0.22$ & $0.66 \pm 0.08$ & \\
\hline Retinol binding protein, $\mathrm{mg} / \mathrm{L}$ & $19.30 \pm 4.06$ & $21.56 \pm 1.14$ & & $14.72 \pm 2.76$ & $19.22 \pm 1.81$ & \\
\hline Tumor necrosis factor- $\alpha, \mathrm{pg} / \mathrm{mL}$ & $32.71 \pm 19.7$ & $50.61 \pm 13.64$ & & $33.74 \pm 28.05$ & $69.73 \pm 28.62$ & \\
\hline Inflammation score & $0.71 \pm 0.29$ & $0.35 \pm 0.08$ & 0.07 & $0.80 \pm 0.37$ & $0.33 \pm 0.16$ & 0.1 \\
\hline Health score ${ }^{b}$ & $5.43 \pm 1.67$ & $3.84 \pm 0.61$ & & $5.20 \pm 1.83$ & $4.83 \pm 1.09$ & \\
\hline
\end{tabular}

${ }^{a}$ All hemoglobin phenotypes included.

${ }^{b}$ Health score is the sum of the number of episodes of pain crisis, infection, hospital admission, and/or blood units received.

29.3\%) in children with plasma retinol concentrations below normal compared to those with levels within the normal range in both the age-adjusted and age-unadjusted analyses $(P>0.1)$. The same trend was observed when the analysis included only boys with HbSS genotype with plasma retinol levels $<20 \mu \mathrm{g} / \mathrm{dL}$ vs $\geq 20 \mu \mathrm{g} / \mathrm{dL}$ (Figure $2 \mathrm{~B}, P>0.1$ ). The mean stimulation indexes of cell cultures from children with plasma retinol concentrations and retinol binding protein below normal were $18.2 \%$ lower than those of children with normal concentrations of plasma retinol but retinol binding protein below normal level (Figure 2C, $P>0.1$ ). Mean lymphocyte proliferative responses of peripheral blood mononuclear cells obtained from children with inflammation were $12 \%$ lower than those of children without inflammation, although differences were not statistically significant (graph not shown). A dose-dependent decrease (18.2\% to $57.6 \%$ ) in the rate of DNA synthesis or ${ }^{3} \mathrm{H}$-thymidine uptake expressed as counts per minute in PHA-treated cells, corrected for baseline counts per minute, was seen with increased health scores (Figure 2D, $P<0.05$ to $P=0.1$ ).

\section{Interleukin-2 Concentration as a Function of Plasma Retinol, Sex, Inflammation, and Health Scores}

In nonactivated cultures, the mean IL-2 concentrations were higher in cultures of peripheral blood mononuclear cells obtained from children with plasma retinol below normal compared to those with normal concentrations (Figure
3A, $P<0.05)$. In cells treated with $2.5,5$, and $10 \mu \mathrm{g} / \mathrm{mL}$ PHA, the mean IL-2 concentrations were 11\%-26.6\% lower in children with plasma retinol concentrations below normal than in those with normal concentrations $(P>0.1)$.

Contrary to what we expected, the mean IL-2 activity of cells treated with $15 \mu \mathrm{g} / \mathrm{mL}$ PHA was marginally higher for children with plasma retinol below normal than in children with plasma retinol $\geq 20 \mu \mathrm{g} / \mathrm{mL}$.

Mean IL-2 concentrations in PHA-treated cultures from boys with HbSS genotype and plasma retinol below normal levels were $10.6 \%$ lower than those of boys with $\mathrm{HbSS}$ and normal plasma retinol concentrations; however, the differences were not statistically significant (Figure 3B).

In nonactivated cells, the mean IL-2 concentration of nonactivated cells obtained from children with plasma retinol and retinol binding protein below normal levels tended to be higher than that obtained from children with plasma retinol and retinol binding protein within the normal range (Figure 3C, $P=0.05$ ). However, as expected, the mean IL2 concentrations of PHA-treated cells obtained from children with plasma retinol and retinol binding protein below normal levels were $8.6 \%-27.6 \%$ lower than those of children with normal plasma retinol but retinol binding protein below normal (Figure $3 \mathrm{C}, P=0.1$ for $5 \mu \mathrm{g} / \mathrm{mL}$ and $15 \mu \mathrm{g} / \mathrm{mL}$ PHA). When plasma retinol concentrations were not taken into account, we observed slightly higher (mean \pm SD) IL-2 activity in cells incubated with $5 \mu \mathrm{g} / \mathrm{mL}$ PHA from girls $(6.43 \pm 2.712 \mathrm{U} / \mathrm{mL})$ than from boys $(4.478 \pm 2.25 \mathrm{U} / \mathrm{mL}$, 
Table 4. Mean ( \pm SEM) Age and Clinical Status of Boys and Girls With Sickle Cell Disease Independent of Vitamin A Status

\begin{tabular}{|c|c|c|}
\hline Variable & Boys $(n=34)$ & Girls $(n=25)$ \\
\hline Age, years & $6.62 \pm 0.71$ & $7.63 \pm 1.01$ \\
\hline Plasma retinol, $\mu \mathrm{g} / \mathrm{dL}$ & $49.8 \pm 4.90$ & $68.1 \pm 5.1^{\mathrm{a}}$ \\
\hline Weight, kg & $25.78 \pm 2.65$ & $25.64 \pm 3.26$ \\
\hline Weight percentile & $34.05 \pm 5.59$ & $39.7 \pm 6.60$ \\
\hline Height, $\mathrm{cm}$ & $121.32 \pm 4.76$ & $119.86 \pm 7.27$ \\
\hline Height percentile & $35.76 \pm 5.95$ & $41.66 \pm 6.65$ \\
\hline Pain crises & $0.72 \pm 0.16$ & $1.00 \pm 0.38$ \\
\hline Units of blood & $0.91 \pm 0.37$ & $1.41 \pm 0.49$ \\
\hline Infections & $0.66 \pm 0.16$ & $0.50 \pm 0.18$ \\
\hline Hospitalizations & $1.43 \pm 0.33$ & $1.57 \pm 0.47$ \\
\hline Hematocrit, \% & $26.98 \pm 0.93$ & $28.48 \pm 0.87$ \\
\hline Hemoglobin, $\mathrm{g} / \mathrm{dL}$ & $8.58 \pm 0.32$ & $9.00 \pm 0.36$ \\
\hline White blood cells $\times 10^{6} / \mathrm{mL}$ & $13.30 \pm 0.84$ & $11.72 \pm 1.06$ \\
\hline C-reactive protein, mg/L & $8.85 \pm 0.39$ & $4.444 \pm 1.2$ \\
\hline Alpha-1-acid glycoprotein, g/L & $0.689 \pm 0.06$ & $0.689 \pm 0.05$ \\
\hline Retinol binding protein, mg/L & $21.02 \pm 1.52$ & $21.63 \pm 1.64$ \\
\hline $\begin{array}{l}\text { Tumor necrosis factor alpha, } \\
\mathrm{pg} / \mathrm{mL}\end{array}$ & $59.4 \pm 17.89$ & $32.55 \pm 14.04$ \\
\hline Inflammation score & $0.412 \pm 0.12$ & $0.36 \pm 0.098$ \\
\hline Health score ${ }^{b}$ & $3.82 \pm 0.65$ & $4.35 \pm 1.05$ \\
\hline
\end{tabular}

${ }^{\mathrm{a}} P<0.05$; girls had higher mean plasma retinol concentrations than boys.

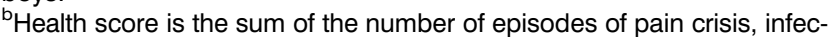
tion, hospital admission, and/or blood units received.

$P>0.1)$. IL-2 concentration in the supernatant of PHAactivated cultures was not significantly affected by inflammation (graph not shown). When cells were activated with 5, 10, and $15 \mu \mathrm{g} / \mathrm{mL} \mathrm{PHA}$, there was a small decrease in the mean IL-2 activity (13.3\%-36.5\%) with increasing health scores (Figure 3D).

\section{Clinical Status and In Vitro Immunity in Children With $\beta$-Thalassemia}

Despite the small sample size, data for selected measurements were also analyzed as a function of $\beta$-thalassemia subgroups. Children with $\mathrm{HbS}^{\text {thal }}$ genotype $(n=3)$ had a slightly higher mean ( \pm SEM) CRP concentration $(3.0 \pm 1.70 \mathrm{mg} / \mathrm{L})$ than children with $\mathrm{HbS} \beta^{+ \text {thal }}$ genotype $(\mathrm{n}=5)(0.62 \pm 0.62 \mathrm{mg} / \mathrm{L}, P=0.08)$. Mean $( \pm \mathrm{SEM})$ plasma retinol concentrations were not significantly different between children with $\mathrm{HbS} \beta^{\text {othal }}(53.53 \pm 0.30 \mu \mathrm{g} / \mathrm{dL})$ and those with $\mathrm{HbS} \beta^{+ \text {thal }}$ genotype $(56.60 \pm 13.50 \mu \mathrm{g} / \mathrm{dL})$. Also, no significant difference was observed between both groups with all other measurements (data not shown).

\section{Correlation Coefficients and Multiple Regression Analysis}

Lymphocyte proliferative responses to PHA positively and significantly correlated with retinol binding protein concentrations, negatively correlated with health scores, pain crises,
Table 5. Mean ( \pm SEM) Age and Clinical Status of Children with Sickle Cell Disease as a Function of Inflammation

\begin{tabular}{|c|c|c|}
\hline Variable & $\begin{array}{c}\text { Without } \\
\text { Inflammation } \\
(n=40)\end{array}$ & $\begin{array}{c}\text { With } \\
\text { Inflammation }^{a} \\
(n=19) \\
\end{array}$ \\
\hline Age, years & $8.354 \pm 0.753$ & $6.09 \pm 0.811^{b}$ \\
\hline Plasma retinol, $\mu \mathrm{g} / \mathrm{dL}$ & $60.9 \pm 7.0$ & $50.90 \pm 4.3^{c}$ \\
\hline Weight, kg & $28.39 \pm 2.58$ & $18.864 \pm 2.21$ \\
\hline Weight percentile & $38.08 \pm 5.16$ & $32.393 \pm 7.63$ \\
\hline Height, cm & $125.64 \pm 4.60$ & $107.23 \pm 7.14$ \\
\hline Height percentile & $39.54 \pm 5.24$ & $34.64 \pm 8.42$ \\
\hline Pain crises & $0.892 \pm 0.31$ & $0.688 \pm 0.24$ \\
\hline Units of blood & $1.333 \pm 0.398$ & $0.563 \pm 0.33$ \\
\hline Infections & $0.526 \pm 0.15$ & $0.688 \pm 0.18$ \\
\hline Hospitalizations & $1.60 \pm 0.35$ & $1.25 \pm 0.43$ \\
\hline Hematocrit, \% & $27.45 \pm 0.81$ & $28.00 \pm 1.08$ \\
\hline Hemoglobin, g/dL & $8.81 \pm 0.31$ & $8.673 \pm 0.39$ \\
\hline White blood cells $\times 10^{6} / \mathrm{mL}$ & $12.364 \pm 0.79$ & $13.15 \pm 1.23$ \\
\hline Health score ${ }^{d}$ & $4.154 \pm 0.77$ & $3.78 \pm 0.72$ \\
\hline \multicolumn{3}{|c|}{$\begin{array}{l}{ }^{a} \text { Inflammation is defined as C-reactive protein }>10 \mathrm{mg} / \mathrm{L} \text { and/or } \alpha 1 \text {-acid } \\
\text { glycoprotein }>1.0 \mathrm{~g} / \mathrm{L} \text {. } \\
{ }^{\mathrm{b}} P<0.05 \text {. } \\
{ }^{\mathrm{c}} P=0.1 \text {. } \\
{ }^{\mathrm{C}} \text { Health score is the sum of the number of episodes of pain crisis, infec- } \\
\text { tion, hospital admission, and/or blood units received. }\end{array}$} \\
\hline
\end{tabular}

and units of blood received (Table $6, P<0.05$ ), and nonsignificantly correlated with infection episodes. Although the same trend was observed between IL-2 concentrations in the supernatants of PHA-treated cultures and measures of clinical status, none of the correlations was statistically significant (data not shown). Plasma retinol concentrations positively correlated with weight percentile $(r=0.181)$, height percentile $(r=0.222)$, IL-2 concentration $(5 \mu \mathrm{g} / \mathrm{mL}$ PHA only, $r=0.184)$, and number of blood units received $(r=0.329$, $P<0.05)$. Plasma retinol concentrations negatively correlated with inflammation scores $(r=-0.235, P<0.05)$ and nonsignificantly with the number of pain crisis episodes $(r=-0.170)$ and hospitalizations $(r=-0.127)$. Multiple regression analysis with IL-2 and/or lymphocyte proliferative responses to PHA as dependent variables did not show any strong association with anthropometric measurements, inflammation, hematologic measurements, or sex.

\section{DISCUSSION}

Our study reveals a few important observations: (1) no child $<5$ years of age had a plasma retinol concentration below normal $(<20 \mu \mathrm{g} / \mathrm{dL})$; (2) vitamin A deficiency was observed in $7 / 59$ children (nearly $12 \%$ ), a percentage that is significantly higher than that observed $(0.6 \%-1.5 \%, 95 \%$ confidence interval, mean of $1 \%$ ) in American children of the same age range ${ }^{23,24}$; (3) while the weight and height mean percentiles were $<50^{\text {th }}$ percentile, severe growth deficits (weight or height $<3^{\text {rd }}$ percentile) were not common in the overall population. Nearly $43 \%(3 / 7)$ of the children with plasma retinol below normal, compared with $22 \%$ of those with normal plasma retinol concentrations, had weight 
Kuvibidila, $S R$

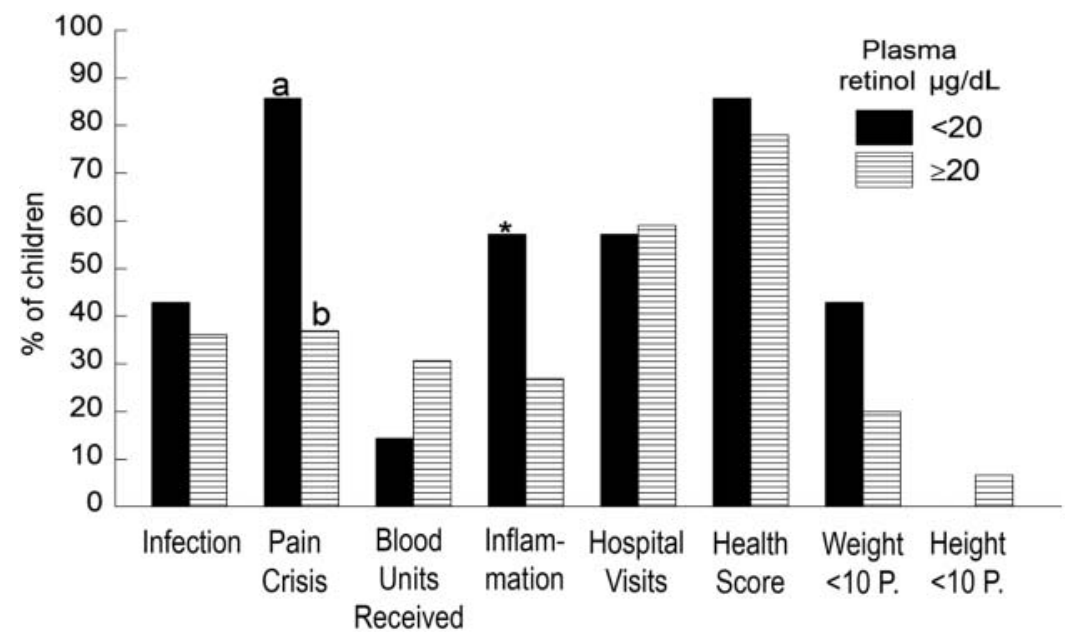

Figure 1. Percentage of children with sickle cell disease who had any of the listed health problems as a function of plasma retinol concentration below normal $(<20 \mu \mathrm{g} / \mathrm{dL})$ and within the normal range ( $\geq 20 \mu \mathrm{g} / \mathrm{dL})$. A higher percentage of children with plasma retinol $<20 \mu \mathrm{g} / \mathrm{dL}$ vs children with levels $\geq 20 \mu \mathrm{g} / \mathrm{dL}$ had pain crisis episodes (chi-square test, $a>b, P<0.05$ ) or inflammation $(* P=0.1)$. For all other measurements, no significant differences were detected.

below the $10^{\text {th }}$ percentile. However, while no child with plasma retinol concentration below normal had height below the $10^{\text {th }}$ percentile, nearly $7 \%$ of those with adequate plasma retinol levels did, and only 2 children in the overall population had height below the $3^{\text {rd }}$ percentile. The lack of a high prevalence of severe growth deficits could be attributed to excellent healthcare and disease management and may also suggest that either macronutrient intake or utilization were adequate.

Although differences were small and not statistically significant, the overall health status (weight percentile, height percentile, and inflammation scores) appeared to be worse in boys than in girls. Boys also had lower mean plasma retinol levels and IL-2 activity in the supernatant of PHA-treated cells than girls. Although the experimental design did not allow us to identify the mechanisms of these differences, published data about adults without SCD have clearly demonstrated significant sex differences in the risk of infections and in immune responses to vaccines. ${ }^{25,26}$ Women have lower incidences and severity of many viral, bacterial, and protozoan infections than men, and they also mount stronger humoral and cell-mediated immune responses to infection. ${ }^{26}$ In a 2013 study, Sankaran-Walters et al reported that women had a higher degree of immune activation of CD4+ and CD8+ blood- and gut-associated lymphocytes than men, and women also produced higher mean Th1associated cytokines (TNF- $\alpha, \mathrm{IL}-1 \beta$, and IL-17) that are required to recover from respiratory infections but lower Th2-associated cytokines (IL-4 and IL-10). ${ }^{26}$ Sex differences that may increase the risk of certain types of viral and bacterial infections start in infancy or prepubertal periods, with higher incidences and mortality rates in boys than in girls 0-14 years of age. ${ }^{25}$ At least in adults, certain measurements of SCD severity vary by sex. In one study, the prevalence and severity of pain crises were reported to be lower in females than in males; and the mean age at death was higher in females (29.1 years) than in males (26.2 years). ${ }^{27}$ In our study, the mean number of pain crises did not vary by sex, and the mean number of infections was only slightly and nonsignificantly lower in girls than in boys. However, as expected, the mean concentrations of CRP, TNF- $\alpha$, and inflammatory scores were higher in boys than in girls. These factors may explain in part the lower mean plasma retinol levels in boys than in girls (Table 4). Because of the paucity of data on differences in immune responses in boys vs girls with SCD or adult male and female patients with SCD, this is an area of interest for future studies.

We observed a positive and significant correlation between lymphocyte proliferative responses to PHA and retinol binding protein (a surrogate marker of vitamin A status, especially in the absence of inflammation or overt protein-energy malnutrition) but a negative correlation with health scores, blood units received, pain crises, and infections. Plasma retinol positively correlated with IL-2 concentrations in culture activated with $5 \mu \mathrm{g} / \mathrm{mL}$ PHA. From the current data, we are unable to state which came first: inadequate vitamin A status affecting health scores (pain crises, inflammation assessed by (RP) and in vitro immune function or the opposite. In either case, pain crisis episodes are usually associated with inflammation and reduced nutrient intake (including vitamin A), and these factors may in turn affect immune function.

Several studies have been conducted on vitamin A status in children with SCD and its influence on health status or the role of vitamin A status in lymphocyte proliferation and cytokine secretion in individuals and laboratory animals without SCD. ${ }^{1-3,16,28-32}$ The negative effect of suboptimal vitamin A status on immunity has been clearly demonstrated. In 2 studies conducted on blood lymphocytes obtained from healthy adult subjects without SCD, the addition of vitamin A (in the form of retinoic acid) to culture medium resulted in increased IL-2 secretion, lymphocyte proliferation, and dendritic cell maturation. ${ }^{33,34}$ However, to our knowledge, 

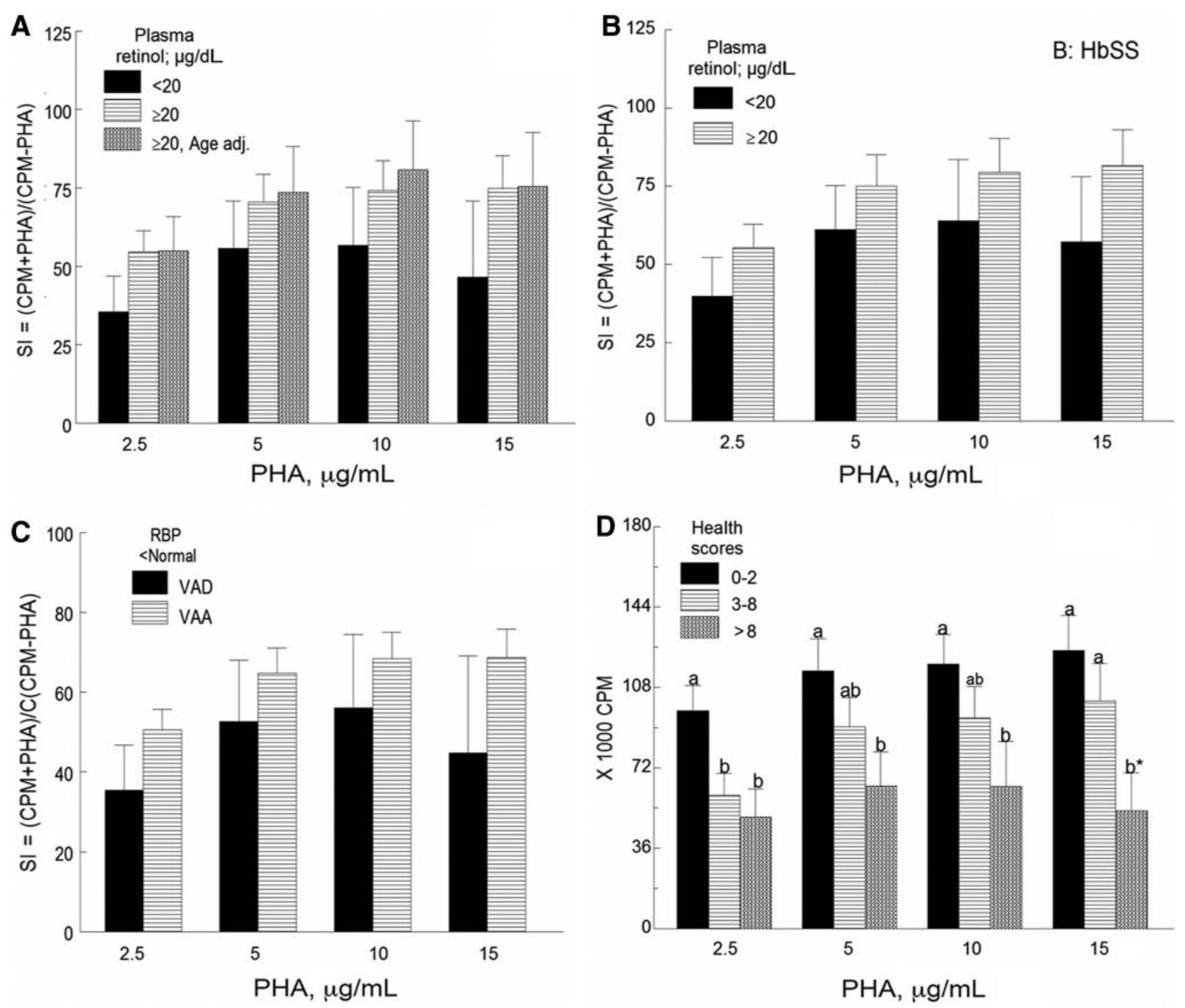

Figure 2. Lymphocyte proliferative responses of peripheral blood mononuclear cells to phytohemagglutinin (PHA) (A) as a function of plasma retinol concentration ( $n=7$ VAD and $n=52$ VAA children); (B) in boys with HbSS and VAD ( $n=5$ ) and boys with HbSS and VAA $(n=18)$; $(C)$ in children with retinol binding protein (RBP) and plasma retinol below normal $(n=6)$ and children with normal plasma retinol but RBP below normal $(n=31)$; and $(D)$ as a function of health scores $(n=29, n=20$, and $n=8$ for health scores $0-2,3-8$, and $>8$, respectively). For $2 A$, $2 B$, and $2 C$, no significant differences in mean stimulation indexes (SI) were found between children with plasma retinol levels $<20 \mu \mathrm{g} / \mathrm{dL}$ and those with levels $\geq 20 \mu \mathrm{g} / \mathrm{dL}$. For 2D, for each PHA concentration $(2.5,5,10$, or $15 \mu \mathrm{g} / \mathrm{mL})$, a dose-dependent decrease in the rate of DNA synthesis was seen with increased health scores $(\boldsymbol{P}<\mathbf{0 . 0 5}$ to $\boldsymbol{P}=\mathbf{0 . 1})$. Values are mean $\pm \mathrm{SEM}$. CPM, counts per minute; VAA, vitamin A-adequate, VAD, vitamin A-deficient.

ours is the first study in which in vitro immune function (lymphocyte proliferation, IL-2 secretion) and plasma levels of TNF- $\alpha$ were investigated as a function of vitamin A status in children with SCD. The small differences persisted after taking into account hemoglobin genotype and sex (comparing boys with HbSS and plasma retinol below normal concentration and those with levels within the normal range). The high spontaneous IL-2 secretion observed in PHAuntreated cultures may suggest that lymphocytes from vitamin A-deficient children are activated in vivo as a result of underlying problems such as continuous free radical formation and hemolysis. One other important observation is that
6/7 children with plasma retinol concentrations below normal were children with HbSS genotype, consistent with the fact that patients with this hemoglobin genotype tend to have a more severe disease than those with other genotypes (for example, $\mathrm{HbSC}$ or $\mathrm{HbS}^{+ \text {thal }}$ ).

We did not investigate the mechanisms of impaired lymphocyte proliferation in the current study. However, we can speculate that these mechanisms could be related to differences in the number of immunocompetent $T$ lymphocytes between vitamin A-deficient and vitamin A-adequate children or to impaired gene expression of IL-2, IL-2 receptors, or other factors that regulate lymphocyte proliferative responses 
A

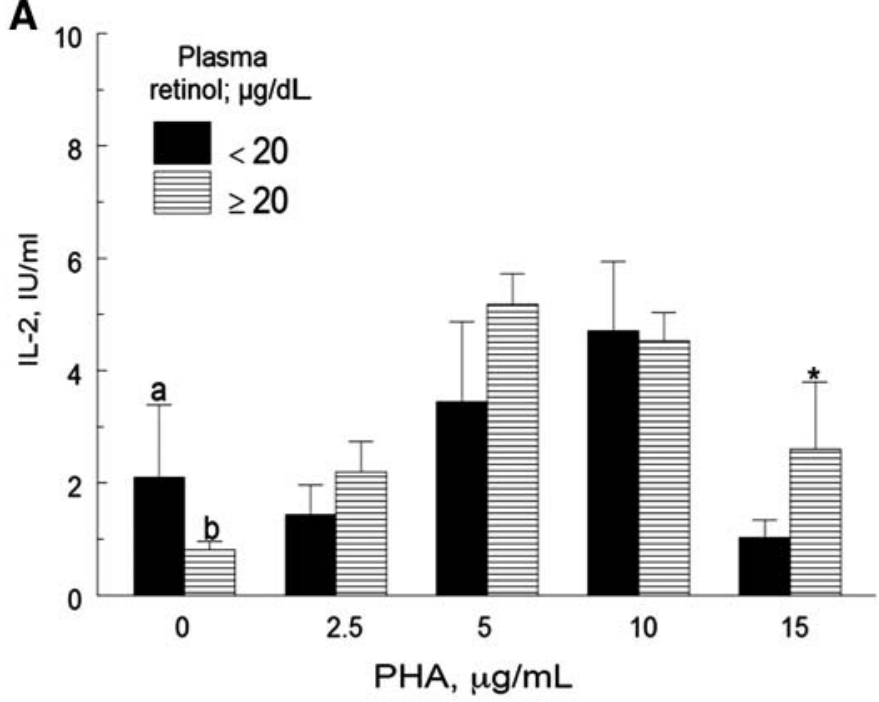

C

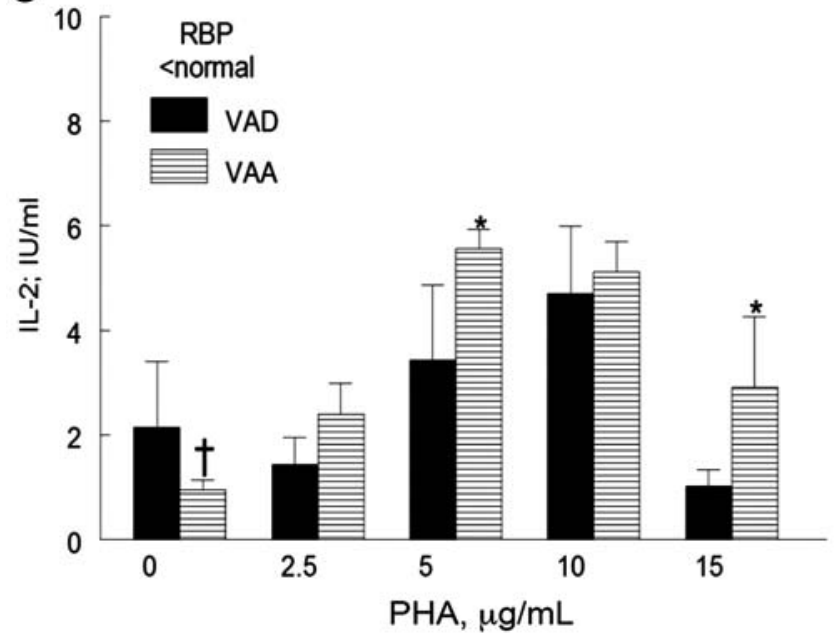

B 8

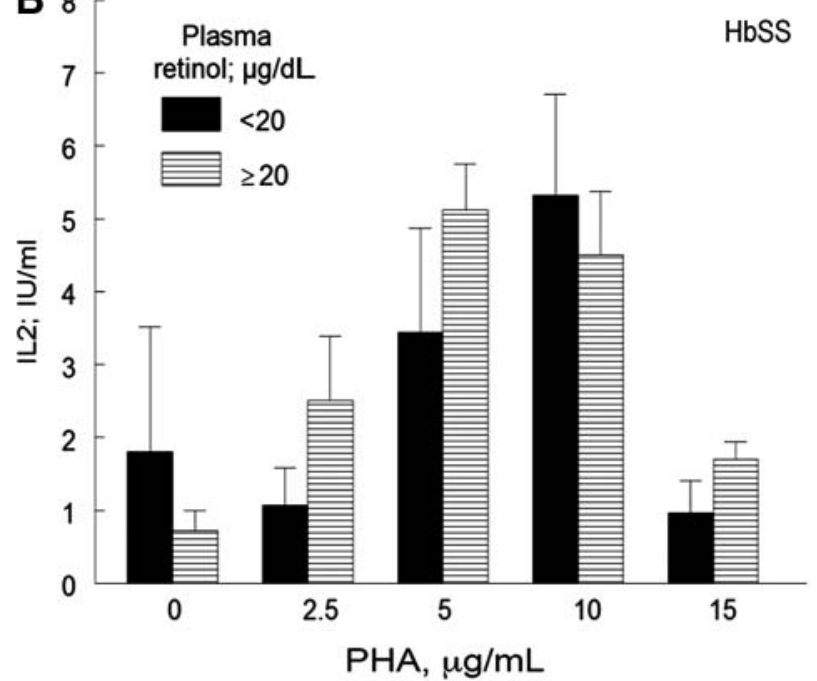

D 8 Health

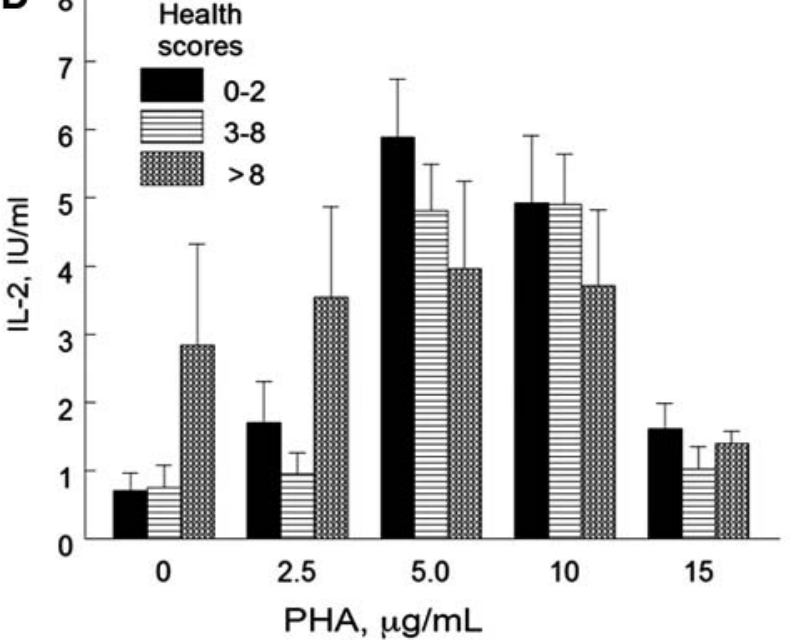

Figure 3. Interleukin-2 (IL-2) concentrations in phytohemagglutinin (PHA)-treated and untreated peripheral blood mononuclear cells in children with sickle cell disease $(A)$ as a function of plasma retinol levels $(n=52$ children with normal plasma retinol levels and $n=7$ children with deficient plasma retinol levels); (B) in boys with HbSS and plasma retinol below normal $(n=5)$ and boys with normal plasma retinol $(n=18) ;(C)$ in children with retinol binding protein (RBP) and plasma retinol below normal $(n=6)$ and children with normal plasma retinol but RBP below normal $(n=31)$; and $(D)$ as a function of health scores $(n=29, n=20$, and $n=8$ for health scores $0-2,3-8$, and $>8$, respectively). For $3 A$ and $3 C$ (PHA $0 \mu \mathrm{g} / \mathrm{mL}$ ), the $\mathrm{mean}$ IL-2 concentrations of children with plasma retinol $<20 \mu \mathrm{g} / \mathrm{dL}$ were higher than those with plasma retinol $\geq 20 \mathrm{mg} / \mathrm{dL}$ (a $>\mathrm{b}$, $P<0.05$ in $3 A ;+P=0.052$ in $3 C$ ). For PHA 5 and/or $15 \mu \mathrm{g} / \mathrm{mL}$, the mean IL-2 concentrations of children with plasma retinol $<20 \mu \mathrm{g} / \mathrm{dL}$ were lower than those of children with plasma retinol $\geq 20 \mu \mathrm{g} / \mathrm{dL}$ ( $* P<0.1$ but $>0.05$ in $3 \mathrm{C}$ ). The means of IL-2 activity between children plasma retinol $<\mathbf{2 0} \mu \mathrm{g} / \mathrm{dL}$ and those with levels $\mathbf{2 0} \boldsymbol{\mu} \mathrm{g} / \mathrm{dL}$ (3B) and as a function of health scores (3D) were not statistically different. Values are mean \pm SEM. VAA, vitamin A-adequate, VAD, vitamin A-deficient.

to mitogens and antigens. $3,33,34$ Low percentages of CD4+ and CD8+ T cells previously have been reported in patients without SCD but with vitamin A deficiency, and they were corrected after the addition of vitamin A supplements. ${ }^{35}$

Vitamin A, through its metabolite all-trans retinoic acid, has been shown to modulate adaptive immunity through various mechanisms such as regulation of $T$ cell differentiation and activation, secretion of proinflammatory and antiinflammatory cytokines, expression of cell receptors, and proteins such as cyclin D3 that regulate T cell proliferation. ${ }^{36}$ Retinoic acid has also been shown to downregulate apoptosis of activated human lymphocytes in vitro and to regulate the expression of nuclear factors of activated human $T$ cells that control the production and/or secretion of IL-2. ${ }^{34,37}$ Blocking of retinoic acid receptor alpha abrogated the retinoic acid effect on IL-2 secretion and cell proliferation. ${ }^{38}$ This finding implies that any of these mechanisms could be responsible for the reduced lymphocyte proliferation and/or IL-2 secretion in activated lymphocytes from children with SCD and below-normal plasma retinol concentration.

The observed concentrations of plasma retinol in our study were higher than those reported by other investigators who have studied American and non-American children with SCD. ${ }^{16,22,29}$ Three possible explanations could account for 
Table 6. Correlation Coefficients ( $r$ ) Between Indicators of Clinical Status and Lymphocyte Proliferative Responses to Phytohemagglutinin (PHA) (corrected for baseline ${ }^{3} \mathrm{H}$ thymidine uptake) in Children With Sickle Cell Disease

\begin{tabular}{|c|c|c|c|c|}
\hline Variable & $\begin{array}{c}\text { PHA } \\
2.5 \mu \mathrm{g} / \mathrm{mL}\end{array}$ & $\begin{array}{c}\text { PHA } \\
5 \mu \mathrm{g} / \mathrm{mL}\end{array}$ & $\begin{array}{c}\text { PHA } \\
10 \mu \mathrm{g} / \mathrm{mL}\end{array}$ & $\begin{array}{c}\text { PHA } \\
15 \mu \mathrm{g} / \mathrm{mL}\end{array}$ \\
\hline $\begin{array}{l}\text { Retinol binding } \\
\text { protein }\end{array}$ & $0.242^{a}$ & $0.307^{a}$ & $0.349^{a}$ & $0.367^{a}$ \\
\hline Health score ${ }^{b}$ & $-0.319^{a}$ & $-0.272^{a}$ & $-0.287^{a}$ & $-0.326^{a}$ \\
\hline Pain crises & $-0.252^{\mathrm{a}}$ & -0.182 & -0.195 & -0.195 \\
\hline Units of blood & -0.195 & $-0.243^{a}$ & $-0.266^{\mathrm{a}}$ & $-0322^{a}$ \\
\hline Infections & -0.151 & -0.138 & -0.172 & -0.042 \\
\hline
\end{tabular}

${ }^{a}$ The $(r)$ value is significantly different from zero $(P<0.05)$.

${ }^{b}$ Health score is the sum of the number of episodes of pain crisis, infection, hospital admission, and/or blood units received.

the difference: (1) methods used for plasma retinol assay, (2) use of vitamin supplements, and (3) differences in the population. In our study, plasma retinol was assayed by fluorometric methods, whereas other investigators have used high-performance liquid chromatography. Additionally, Dougherty et al included only children with HbSS genotype in their study. ${ }^{22}$ Because micronutrient (multivitamin-mineral) supplements are commonly used in the United States, this practice may, in part, explain the high plasma retinol concentrations in our studied population.

Our study has several limitations: (1) the small sample size, (2) cross-sectional nature of the study, (3) lack of information on vitamin A intake, and (4) lack of data on the mechanisms of impaired lymphocyte proliferation and/or IL-2 secretion. These issues will be addressed in a future study.

\section{CONCLUSION}

Our study suggests that approximately $12 \%$ of the researched children with SCD had plasma retinol concentrations below normal. The affected children had poorer in vitro immune function and health compared to those with an adequate vitamin A status. Considering the negative effects of poor immunity on infection, a predisposing factor for pain crisis, our data suggest that routine measurement of plasma retinol should be performed in children with SCD, especially those $>5$ years of age.

\section{ACKNOWLEDGMENTS}

This work was supported by general research funds from the Louisiana State University Health Sciences Center, Department of Pediatrics, Division of Hematology/Oncology and the Sickle Cell Center of Southern Louisiana, New Orleans. The authors have no conflict of interest (no direct financial benefits in the subject matter of this article) to report.

We thank all parents who allowed their children to be a part of the study; the nurses who coordinated blood drawing; Mr Gerald Lane for assisting in the isolation of peripheral blood mononuclear cells, in vitro cell cultures, and measurements of acute phase proteins; and Ms Leone Coe for her very important feedback and for editing the manuscript. Special thanks go to Dr Lolie Yu for her useful suggestions at dif- ferent phases of the study, including the preparation of the manuscript.

\section{REFERENCES}

1. Jason J, Archibald LK, Nwanyanwu OC, et al. Vitamin A levels and immunity in humans. Clin Diagn Lab Immunol. 2002 May;9 (3):616-621.

2. Mora JR, Iwata M, von Andrian UH. Vitamin effects on the immune system: vitamins $A$ and $D$ take centre stage. Nat Rev Immunol. 2008 Sep;8(9):685-689. doi: 10.1038/nri2378.

3. Bono MR, Tejon G, Flores-Santibañez F, Fernandez D, Rosemblatt M, Sauma D. Retinoic acid as a modulator of T cell immunity. Nutrients. 2016 Jun 13;8(6). doi: 10.3390/nu8060349.

4. Kim MH, Taparowsky EJ, Kim CH. Retinoic acid differentially regulates the migration of innate lymphoid cell subsets to the gut. Immunity. 2015 Jul 21;43(1):107-119. doi: 10.1016/j. immuni.2015.06.009.

5. Kaufman DR, De Calisto J, Simmons NL, et al. Vitamin A deficiency impairs vaccine-elicited gastrointestinal immunity. J Immunol. 2011 Aug 15;187(4):1877-1883. doi: 10.4049/ jimmunol.1101248.

6. Czarnewski P, Das S, Parigi SM, Villablanca EJ. Retinoic acid and its role in modulating intestinal innate immunity. Nutrients. 2017 Jan 13;9(1). doi: 10.3390/nu9010068.

7. Brown CC, Noelle RJ. Seeing through the dark: new insights into the immune regulatory functions of vitamin A. Eur J Immunol. 2015 May;45(5):1287-1295. doi: 10.1002/eji.201344398.

8. Warrier RP, Kuvibidila S, Gordon L, Humbert J. Transport proteins and acute phase reactant proteins in children with sickle cell anemia. J Natl Med Assoc. 1994 Jan;86(1):33-39.

9. Zemel BS, Kawchak DA, Ohene-Frempong K, Schall Jl, Stallings VA. Effects of delayed pubertal development, nutritional status, and disease severity on longitudinal patterns of growth failure in children with sickle cell disease. Pediatr Res. 2007 May;61(5 Pt 1):607-613.

10. Bennett EL. Understanding growth failure in children with homozygous sickle-cell disease. J Pediatr Oncol Nurs. 2011 MarApr;28(2):67-74. doi: 10.1177/1043454210382421.

11. Al-Sagladi AW, Cipolotti R, Fijnvandraat K, Brabin BJ. Growth and nutritional status of children with homozygous sickle cell disease. Ann Trop Paediatr. 2008 Sep;28(3):165-189. doi: $10.1179 / 146532808 \times 335624$.

12. Singhal A, Thomas $P$, Cook R, Wierenga K, Serjeant G. Delayed adolescent growth in homozygous sickle cell disease. Arch Dis Child. 1994 Nov;71(5):404-408.

13. Hyacinth $\mathrm{HI}$, Gee BE, Hibbert JM. The role of nutrition in sickle cell disease. Nutr Metab Insights. 2010 Jan 1;3:57-67.

14. Prasad AS, Beck FW, Kaplan J, et al. Effect of zinc supplementation on incidence of infections and hospital admissions in sickle cell disease (SCD). Am J Hematol. 1999 Jul;61(3):194-202.

15. Zemel BS, Kawchak DA, Fung EB, Ohene-Frempong K, Stallings VA. Effect of zinc supplementation on growth and body composition in children with sickle cell disease. Am J Clin Nutr. 2002 Feb;75(2):300-307.

16. Behera S, Dixit S, Bulliyya G, Kar SK. Vitamin A status and hematological values in sickle cell disorder cases. Indian J Med Sci. 2012 Jul-Aug;66(7-8):169-174. doi: 10.4103/00195359.114180.

17. Gamble MV, Ramakrishnan R, Palafox NA, Briand K, Berglund L, Blaner WS. Retinol binding protein as a surrogate measure for serum retinol: studies in vitamin A-deficient children from the Republic of the Marshall Islands. Am J Clin Nutr. 2001 Mar;73 (3):594-601. 
18. Larson LM, Addo OY, Sandalinas F, et al. Accounting for the influence of inflammation on retinol-binding protein in a population survey of Liberian preschool-age children. Matern Child Nutr. 2017 Apr;13(2). doi: 10.1111/mcn.12298.

19. Kuvibidila SR, Gardner R, Velez M, Yu L. Iron deficiency, but not underfeeding reduces the secretion of interferon-gamma by mitogen-activated murine spleen cells. Cytokine. 2010 Dec;52 (3):230-237. doi: 10.1016/j.cyto.2010.08.004

20. Hank JA, Surfus J, Gan J, et al. Distinct clinical and laboratory activity of two recombinant interleukin-2 preparations. Clin Cancer Res. 1999 Feb;5(2):281-289.

21. Munro HB. Differences among group means: one way analysis of variance. In: Munro HB, Page IB, eds. Statistical Methods for Health Care Research. 2nd ed. Philadelphia, PA: JB Lippincott Company; 1993:99-128.

22. Dougherty KA, Schall Jl, Kawchak DA, et al. No improvement in suboptimal vitamin A status with a randomized, double-blind, placebo-controlled trial of vitamin A supplementation in children with sickle cell disease. Am J Clin Nutr. 2012 Oct;96 (4):932-940.

23. Second National Report on Biochemical Indicators of Diet and Nutrition in the U.S. Population. Centers for Disease Control and Prevention, National Center for Environmental Health, Division of Laboratory Sciences. 2012:100. https://www.cdc.gov /nutritionreport/pdf/nutrition_book_complete508_final.pdf. Accessed September 8, 2018.

24. Ballew C, Bowman BA, Sowell AL, Gillespie C. Serum retinol distributions in residents of the United States: third National Health and Nutrition Examination Survey, 1988-1994. Am J Clin Nutr. 2001 Mar;73(3):586-593.

25. Muenchhoff $M$, Goulder PJ. Sex differences in pediatric infectious diseases. J Infect Dis. 2014 Jul 15;209 Suppl 3:S120S126. doi: 10.1093/infdis/jiu232.

26. Sankaran-Walters S, Macal M, Grishina I, et al. Sex differences matter in the gut: effect on mucosal immune activation and inflammation. Biol Sex Differ. 2013 May 7;4(1):10. doi: 10.1186/ 2042-6410-4-10.

27. Rami Helvaci M, Ayyildiz O, Gundogdu M. Gender differences in severity of sickle cell diseases in non-smokers. Pak J Med Sci. 2013 Jul;29(4):1050-1054.
28. Wright $D$, Reid $M$, Stennett R. Antioxidant intake in sickle cell disease. Intern J Clin Nutr. 2014;2(3):53-59. doi: 10.12691/ijen-23-2.

29. Schall Jl, Zemel BS, Kawchak DA, Ohene-Frempong K, Stallings VA. Vitamin A status, hospitalizations, and other outcomes in young children with sickle cell disease. J Pediatr. 2004 Jul;145 (1):99-106.

30. Cantorna MT, Nashold FE, Hayes CE. In vitamin A deficiency multiple mechanisms establish a regulatory $\mathrm{T}$ helper cell imbalance with excess Th1 and insufficient Th2 function. J Immunol. 1994 Feb 15;152(4):1515-1522.

31. Nauss KM, Mark DA, Suskind RM. The effect of vitamin A deficiency on the in vitro cellular immune response of rats. $J$ Nutr. 1979 Oct;109(10):1815-1823.

32. Bessler H, Wyshelesky G, Osovsky M, Prober V, Sirota L. A comparison of the effect of vitamin $A$ on cytokine secretion by mononuclear cells of preterm newborns and adults. Neonatology. 2007;91(3):196-202.

33. Ertesvag A, Engedal N, Naderi S, Blomhoff HK. Retinoic acid stimulates the cell cycle machinery in normal T cells: involvement of retinoic acid receptor-mediated IL-2 secretion. $J$ Immunol. 2002 Nov 15;169(10):5555-5563.

34. Engedal N, Ertesvag A, Blomhoff HK. Survival of activated human $T$ lymphocytes is promoted by retinoic acid via induction of IL-2. Int Immunol. 2004 Mar;16(3):443-453.

35. Semba RD, Muhilal, Ward BJ, et al. Abnormal T-cell subset proportions in vitamin-A-deficient children. Lancet. 1993 Jan 2;341(8836):5-8.

36. Engedal N, Gjevik T, Rune Blomhoff R, Blomhoff HK. All-trans retinoic acid stimulates IL-2-mediated proliferation of human $T$ lymphocytes: early induction of cyclin D3. J Immunol. 2006 Sep 1;177(5):2851-2861.

37. Macian F. NFAT proteins: key regulators of T-cell development and function. Nat Rev Immunol. 2005 Jun;5(6):472-484.

38. Hall JA, Cannons JL, Grainger JR, et al. Essential role for retinoic acid in the promotion of CD4(+) T cell effector responses via retinoic receptor alpha. Immunity. 2011 Mar 25;34(3):435-447. doi: 10.1016/j.immuni.2011.03.003.

This article meets the Accreditation Council for Graduate Medical Education and the American Board of Medical Specialties Maintenance of Certification competencies for Patient Care, Medical Knowledge, and Practice-Based Learning and Improvement. 